\title{
Specific Strategies for Applying the Excellent Traditional Chinese Culture to the Construction of the Ideological and Political Education Model based on the Idea of "to Educate People with Courtesy and to Foster People with Morality" for College Students
}

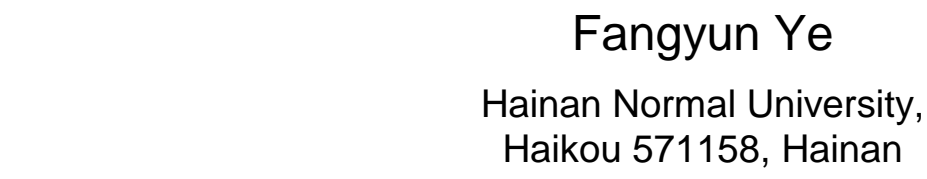

\author{
Ling Li \\ Hainan Normal University, \\ Haikou 571158, Hainan
}

\author{
Weimin Zheng \\ Hainan Normal University, \\ Haikou 571158, Hainan
}

\begin{abstract}
The idea of "to educate people with courtesy and to foster people with morality" is integrated into the ideological and political educational model for college students, so as to clearly know the theory bases, activate practice, and deeply implement the spiritual education. It is incorporated into the four-year college ideological and political educational period by steps and stages based on the specific contents and requirements (i.e. filial piety; love and respect one's elder brother; loyalty; trust; courtesy; righteousness; honesty; humiliation).
\end{abstract}

Keywords- Ideology and Politics; Education Model; College Students; Traditional Culture; Practice; Strategy

\section{Introduction}

In recent years, the human and material resources are more greatly invested by the Party Central Committee for constantly strengthening the college ideological and political education, but the effect is not significant actually. The civilized etiquette is still relatively scarce in college students; moral anomie phenomenon occurs frequently; the problems such as examination cheating, self-injury and suicide, mental defects, moral decline and absent honesty quality have been common. This is because college students are easily affected by the bad social style and lack a self-control power to the outside world. But more importantly, the main internal cause is that the current ideological and political education is not fully implemented in college students, the excellent traditional Chinese culture is not realistically, effectively connected with the contemporary political and cultural ideas, thus making the virtues conveyed by the traditional culture are just floating on the paper-theories are not deeply understood and practice is not expanded. The final consequence is that the education does not influence the students' mind and soul and truly purify their thoughts. Therefore, a new, correct and detailed way for the college ideological and political education model is necessarily sought to change the current situation of the ideological and political education [1].

2. Paying attention to the theory base of the college ideological and political education based on the idea of "to educate people with courtesy and to foster people with morality"

Based on the idea of "to educate people with courtesy and to foster people with morality" and the idea of eight virtues, the construction of the theory base of the current college ideological and political education is necessarily focusing on 
both theories and educational objectives, so that the theory base of the college ideological and political education is constructed according to the "filial piety; love and respect one's elder brother; loyalty; trust; courtesy; righteousness; honesty; humiliation". Meanwhile, this is necessarily incorporated into the four-year college ideological and political educational period by steps and stages.

\subsection{Paying attention to the education of "filial piety; love and respect one's elder brother; courtesy" in the ideological and political education for freshmen}

\subsubsection{Filial piety is the root of morality}

"Filial piety" means that students are required to pay more filial piety for their parents and understand how to comply with the parents' mind. In China, "filial piety" is regarded as the supreme virtue. Xiao (i.e. filial piety) in Chinese is associative compound, and it means "filial piety" in terms of its Chinese structure. It is comprehended as a combination of the last generation with next generation, and also it means "to hand down from generation to generation". In the ideological and political education for freshmen, students are asked to learn how to let parents healthy physically and happy mentally. Thus, they need to foster the body and mind of parents, aiming to promote the family life perfectly satisfactory and happy.

2.1.2 "Love and respect one's elder brother" is a good moral quality

"Love and respect one's elder brother" is a virtue concerning about brothers and sisters. Young brothers need to respect and love their elder brothers. Students are demanded to respect teachers in school. In the social environment, students need to keep polite to the public. At home, elder brothers are required to treat younger brothers like friends; parents will be very happy once younger brothers respect elder brothers. In the ideological and political education for freshmen, the way to get along with brothers is necessarily extended to the interaction between teachers and students or between students themselves, aiming to promote the school environment to be more harmonious.

2.1.3 "Courtesy" is a good example of morality Courtesy is the principle of interpersonal communication. In the society, courteous reception is necessarily understood by people, and then the society can run orderly and smoothly. In the ideological and political education for freshmen, the way to get along with each other is necessarily taught among the students, so that they can pay attention to "courtesy" and become convincing and able to get along with people well. However, keeping "courtesy" is supposed to be moderate - it does not conform to the essence of "courtesy" if "courtesy" is kept too much or less. Therefore, in the ideological and political education, the freshmen are necessarily promoted to know the way of getting along with people and pay attention to the rules.

\subsection{Paying attention to the education of "loyalty" and "trust" in the ideological and political education for sophomores}

\subsubsection{Loyalty is the core of morality}

Loyalty means that people should be fulfill their duties with the greatest diligence. From the structure of Zhong (i.e. loyalty), it is composed of Zhong and Xin (i.e. heart). If a person's heart has deviation, he or she can't be called as a person with "loyalty". In the ideological and political education for sophomores, the education of "loyalty" is necessarily focused-students are guided to seriously fulfill their duties and keep learning. That is to say, students can be responsible for teachers, parents, and society.

2.2.2 Trust is the foundation of morality

Seen from the composition of the Xin (i.e. trust), the left is Ren and the right is Yan, and this means a person should keep her or his word. In the ideological and political education for sophomores, the education of "trust" is focused. That is to say, the education can be respected by 
the students only if their awareness in "trust" is built.

2.3 Paying attention to the education of "righteousness" in the ideological and political education for juniors

Righteousness is an important part of morality. It is reflect from that a person's words and deeds are reasonable, fair and legal. In the ideological and political education for juniors, the education of "righteousness" is emphasized. That is to say, the students are guided to scrupulously abide by their own duty.

2.4 Paying attention to the education of "honesty" and "humiliation" in the ideological and political education for seniors

\subsection{1 "Honesty"}

Honesty means that a person can conduct self-discipline and will never make corruption. In the ideological and political education for seniors, the education of "honesty" is necessarily valued. That is to say, the students' honesty quality is trained, so that they can understand how to control themselves in front of interests and pose constraints on their behaviors using the standard of "honesty".

\subsubsection{Humiliation}

Humiliation means that a person knows to feel shamed and recognize mistakes, and then he or she can work energetically. It is said that a person will become brave once he or she knows humiliation, and then can timely correct self-mistakes and overcome self-annoyance. Senior students will soon get employed by employing units, and it is necessary for them to work with the heart of shame and become socially useful talents.
3. Putting the college ideological and political education based on the idea of "to educate people with courtesy and to foster people with morality" into practice

The college ideological and political education is necessarily widely added into the social practice activities, so that the ideological and political education is more flexible, open and diversified. By reading classics, providing lectures and presentations, watching videos, field investigation, volunteer experience, and a good turn day, the traditional culture is internalized into the mind of the students. Thus, the students can truly use it for improving themselves externally and internationally. Then, the traditional culture can better serve the growth of students and improve the effectiveness of the ideological and political education.

\subsection{Reading the classics in the studies of the Chinese ancient civilization}

In this paper, it is thought that the four major purposes of reading the classics in the studies of the Chinese ancient civilization are supposed to reach.

First, Chinese classics reading course is listed in the college ideological and political education to reflect the excellent traditional Chinese culture to some extent and let students feel the profound national spirit.

Second, Chinese classics reading course in the studies of the Chinese ancient civilization can help cultivate the students' moral quality and sentiments and improve their reading competence and even mandarin competence [2].

Third, Chinese classics reading course is necessarily regarded as a quality-oriented education course. Through the course development, the students' noema, awareness in moral culture, and intelligence are improved. More importantly, the comprehensive training of the students' comprehensive quality is implemented. This is in line with the purpose of China's quality-oriented education. 
Finally, Chinese classics reading course is offered for cultivate the students' autonomous learning initiative and interest. When students are encountering problems in learning, the teachers need to ask students to explore answers through online information search, but should not give the answers immediately.

\subsection{Lectures}

Offering lectures about the studies of the Chinese ancient civilization is the best way to carry out the college ideological and political education; the local lecturers about the studies of the Chinese ancient civilization or the ideological and political teachers are invited to offer related ideological and political lectures, so as to interact with students in teaching and allow students to ask and discuss questions together, and ultimately form a good learning style.

\subsection{Video teaching}

Students are arranged to watch videos such as the Presentation of Awards for People Touching the Heart of China, the Traditional Culture BBS, and the Presentation of Awards for the Young with the Most Beautiful Filial Piety, Extraordinary Four Instructions, and Warm Spring together. The students are encouraged and guided to know the dedication, pay out, and keep an optimistic state of mind through a true story. All these are the essential qualities to learn the ideological and political education and help students achieve the purpose of learning the education.

\subsection{Field experience}

Schools can arrange the students to regularly walk away from the campus and take part in the inspection activities centered at field experience. For example, they can visit the old red army's revolutionary bases or the Chinese learning lectures to assist the students' ideological and political education and let them feel the belongingness of the ideological and political educational contents.

\subsection{Voluntary service}

Volunteering activities are to dynamically and completely integrate the teenagers with the community spirit, so as to conform to the characteristics of the contemporary young college students. The special investigation report of the Chinese Communist Party in 2014 showed that from 2000 to the end of 2014, nearly 90 million person-times got involved in the social volunteer action - China's youth volunteer action, providing the society with more than 4 billion hours of volunteer service. In volunteering activities, the teenagers are growing up through the volunteer service and volunteering team construction. Therefore, China's youth volunteer action has also become the masses public welfare activity which many young people join the most widely and the most famously, and has been fully recognized by the national government [3].

\subsection{A good turn day}

A good turn day means a practice of the ideological and political education giving top priority to the activities of learning from Lei Feng. It, as a long-acting mechanism for the development of the ideological and political education in colleges and universities, has the social, organizational and public welfare characteristics. For example, the college students' ideological and political awareness is promoted in the form of openness, fairness, and righteousness, aiming to push the branding of the activities related to "a good turn day".

4. Enabling the soul education of the ideological and political education model based on the idea of "to educate people with courtesy and to foster people with morality"

Psychological health problem has always been a chronic disease existing in the college students in China, because a soul education is absent in China's education system. The college students' individual psychological health presents their 
personality. Whether an individual can keep a steady and positive attitude toward life, self, and others is the basic standard to decide his or her psychological health.

\section{Conclusion}

People, as many individuals, will be inspired for many times in the entire life; especially in the college period, students are gradually accessing to the mature stage, in which the life inspirations may be the most. People have mood. Psychology will tell people that the generation of emotion is inevitable, because it is produced from the interior and exterior needs of people, or is a natural reflection when some desires are fulfilled or not. Human emotion and mood are bad to control, and thus, different people are naturally divided into different levels [4].

\section{Acknowledgement}

This paper was a finding result of the Marxist theory and Ideological and Political Education Research Project for Hainan Province's Institutions of Higher Learning in 2015, "To Educate People with Courtesy and to Foster People with Morality - Study on the Application of the Excellent Traditional Chinese Culture to the Construction of the Ideological and Political Education Model for College Students" (No.Hnsz2015-15).

\section{References}

[1] Shengwen Zhang, Aihua Tang, Xiuju Feng, et al. Study on the College Ideological and Political Educational Methods under the Guidance of People-oriented Idea [J]. Journal of Management, 2015 (18): 100-101.

[2] Guosheng Zhang. Discussion on the Application of the Excellent Traditional Culture to the College Ideological and Political Education [D]. Central China Normal University, 2014. 9-14.

[3] Yunyun Wan. Study on Promoting the Excellent Traditional Chinese Culture in the Learning of College Students' Ideological and Political Theory Course D]. Anhui University, 2015.29-41.

[4] Dewan LI. Study on the Value and Implementation Ways of the Excellent Traditional Culture in College Ideological and Political Education [D]. Liaoning Normal University, 2013.20-21. 